\title{
TOWS Analysis on Recissbar to Increase Its Competitiveness *
}

\author{
Análisis DOFA en la empresa Recissbar para aumentar su competitividad
}

\author{
Efi Fitriani \\ MSc in Economics, STIE Ekuitas, \\ Bandung - Indonesia, efi.fitriani@ekuitas.ac.id
}

\begin{abstract}
How to cite / Cómo citar
Fitriani, E. (2022). TOWS Analysis on Recissbar to Increase Its Competitiveness. Revista CEA, v. 8, n. 16 , e1876.

https://doi.org/10.22430/24223182.1876
\end{abstract}

Received: 12 June 2021

Accepted: 19 October 2021

\begin{abstract}
This study aims to analyze Recissbar's internal and external factors in order to define strategies to increase its competitiveness. Recissbar is a small business in Bandung (Indonesia) that sells traditional Indonesian foods that are very popular in the community. After collecting primary data (from an indepth interview with the owner of the company), an External Factor Analysis Summary (EFAS) and an Internal Factor Analysis Summary (IFAS) were conducted. Once the company's strengths, weaknesses, opportunities, and threats were identified and a scoring system was established to separate the points that required attention, an analysis using a TOWS graph was performed to determine the most appropriate strategy to implement in the company. This study is descriptive in scope. According to the results and the scores assigned to the external and internal factors, an aggressive growth strategy was found to be the most appropriate. Moreover, the total score of the opportunity and threat factors was 2.5, which suggests that Recissbar responds to existing opportunities by avoiding threats in the same market and has the opportunity to continue to innovate. For its part, the total score of the strength and weakness factors was 2.6, which indicates that Recissbar has the strength of having a good reputation and delicious taste. In general, Recissbar could implement a growth-oriented strategy, particularly by promoting products on social media, cooperating with several mini markets, and doing business-to-business online sales.
\end{abstract}

Keywords: TOWS analysis, competitiveness, strategy.

JEL Classification: M21, O4.

* This article is derived from the project entitled "TOWS Analysis on Recissbar to Increase Its Competitiveness" and has been financed with own resources. 


\section{Highlights}

- Strategies that can lead to competitiveness are defined.

- The TOWS graph makes it possible to identify the best strategies for organizations.

- An organization's growth strategy can include promotion on social media.

\section{Resumen}

Este estudio tiene como objetivo analizar los factores internos y externos en la empresa Recissbar con el fin de definir estrategias para aumentar su competitividad. Recissbar es una pequeña empresa ubicada en Bandung (Indonesia) que comercializa alimentos tradicionales de la cultura indonesia muy populares en la comunidad. Después de recopilar los datos primarios (a partir de una entrevista exhaustiva con el dueño de dicha empresa), se realizó un análisis de factores externos (EFAS por sus siglas en inglés) y de factores internos (IFAS por sus siglas en inglés). Una vez que se identificaron las fortalezas, debilidades, oportunidades y amenazas de la empresa y se estableció un sistema de calificación para separar aquellos ítems que requerían atención, se llevó a cabo un análisis mediante un gráfico DOFA para determinar la estrategia más adecuada a implementar en la empresa. Este estudio tiene un alcance descriptivo. De acuerdo con los resultados y los puntajes asignados a los factores externos e internos, una estrategia de crecimiento agresiva demostró ser la más adecuada. Además, el puntaje total de los factores de oportunidades y amenazas fue 2,5, lo que sugiere que Recissbar responde a las oportunidades existentes evitando las amenazas en el mismo mercado y tiene la posibilidad de continuar innovando. Por su parte, el puntaje total de los factores de fortalezas y debilidades fue de 2,6, lo que indica que Recissbar tiene la fortaleza de tener una buena reputación y un sabor delicioso en sus productos. En general, esta empresa podría implementar una estrategia orientada al crecimiento, particularmente promocionando sus productos en las redes sociales, cooperando con varios minimercados y realizando ventas B2B (de empresa a empresa) en línea.

Palabras clave: análisis DOFA, competitividad, estrategia.

Clasificación JEL: M21, O4.

\section{Highlights}

- Se definen las estrategias que pueden generar competitividad.

- El gráfico DOFA permite identificar las mejores estrategias para las organizaciones.

- La estrategia de crecimiento de una empresa puede incluir la promoción en redes sociales.

\section{INTRODUCTION}

Recissbar is an acronym for Rempeyek Cistik Barokah, a Bandung-based small business that was founded on April 4, 1998. It sells snacks, particularly cheese sticks and peanut brittle, which are indeed traditional Indonesian foods that are extremely popular in the community. Recissbar obtained a Halal permit with No. MUI.JB.NO.01101161120316 and a Home Industry Product License (P-IRT) with No. 2063273010070-21. These certifications helped it with its sales by removing any uncertainty about the characteristics of its products, which would eventually be consumed by the general public. Table 1 shows Recissbar's total revenue in 2016, 2017, and 2018. 
Table 1. Recissbar's revenue for the 2016-2018 period Tabla 1. Ingresos de Recissbar para el periodo 2016-2018

\begin{tabular}{ccc}
\hline Year & Revenue (IDR) & Percentage change \\
\hline 2016 & $367,514,234$ & \\
\hline 2017 & $330,165,415$ & $10.16 \%$ decrease \\
\hline 2018 & $380,438,179$ & $15.23 \%$ increase \\
\hline \multicolumn{3}{c}{ Source: (Interview with Recissbar's CEO, 2019). }
\end{tabular}

According to the data above, there was a fluctuation in terms of revenue, with a decrease of IDR 37,348,819 (10.16\%) from 2016 to 2017 and an increase of IDR 50,272,764 (15.23\%) from 2017 to 2018. One of the reasons for such an increase in revenue in 2018 was Recissbar's collaboration with Bandung's hypermarket.

These revenue fluctuations have caught the attention of Recissbar's managers to such an extent that some of the company's shortcomings have been identified, including product unavailability in the nearest mini market, lack of promotion on social media, and lack of cooperation with supermarkets to sell its products. Such identification, however, has not been the result of any systematic process or business strategy that would have allowed the company to better understand the internal and external factors. Thus, this study aims to (1) analyze Recissbar's internal and external environments and (2) devise strategies to increase profitability.

Companies in a competitive business climate require careful planning (Shpak et al., 2020; VargasHernández et al., 2017) not only for the future but also for potential changes in the short to medium term (Assauri, 2004; van Rijmenam et al., 2019; Oliver \& Parrett, 2018). In strategic planning, it is critical to consider various aspects such as business strategy issues, global technological developments, application and infrastructure requirements, human resources, and financial matters. The strategy that companies need to deal with an increasingly fierce business competition is derived from the analysis of key success factors, a SWOT analysis, and TOWS analysis (see, e.g., the study by Wildan Putera (2016)).

\section{THEORETICAL FRAMEWORK}

According to Daft (2013), an explicit strategy is an action plan that explains the allocation of resources and various activities for a company to face the environment, gain competitive advantage, and achieve its goals. The premise of every strategy is that it must be well aligned with the current major business trends (Hautz et al., 2017). The goal of strategy formulation is to determine how a company will be different from others. Strategies certainly vary over time as environmental conditions change, but in order to remain competitive, companies must design strategies that focus on basic competencies, develop synergies, and create value for customers. In fact, strategies play a leading role in an organization's creativity-performance relationship (Daniel et al., 2011). This generates a competitive advantage under the belief that a company is economically sustainable when it can consistently exceed performance expectations (Cacciolatti \& Lee, 2016). Pearce and Robinson (2013) define strategic management as a series of decisions and actions that result in the formulation and implementation of plans aimed at achieving the company's goals. 
Economic issues of great relevance have been addressed through strategic management. One of these issues is the way traditionally successful organizations have developed capabilities that are difficult to replicate, in addition to technological and organizational resources that have allowed them to innovate (Teece, 2019). For their part, Basset et al. (2018) define strategic management as a set of managerial decisions and actions that determine a company's long-term performance. These decisions include strategy formulation, implementation, and evaluation and control. Excellent business performance is not achieved by chance, but it is determined by the decisions made by managers. Competitive advantages are, thus, gained through strategic management (Shujahat et al., 2017).

There are several tools to identify management strategies (Punt, 2017). One of them is the SWOT analysis, which is the most popular technique for decision making (Zakeri et al., 2018). Its main premise is that strengths and weaknesses are the main factors from an internal point of view, while opportunities and threats are external factors. Particularly, organizations should focus on strengths and opportunities when designing a strategic plan (Abdel-Basset et al., 2018). According to Rangkuti (2015), a SWOT analysis consists in the systematic identification of various factors to formulate a corporate strategy. This analysis has proven to be a very useful tool to carry out comparative analyses and define an effective way to understand an organization's factors that can be applied to various fields, such as the development of renewable energies (Madurai Elavarasan et al., 2020) and the dissemination of information technology applications (Taghavifard et al., 2018), and even as a strategy for the prevention and control of the COVID-19 pandemic (Longhurst et al., 2020; Wang \& Wang, 2020). It has also been used in the food industry to implement strategies that promote food sovereignty (Herdiawan et al., 2019).

In their study, Blake and Gano-an (2020) further direct human resource professionals to act as boundary spanners in order to facilitate strategic teams who are paramount to responding to the external environment for organizational performance. Khatimah et al. (2013) found that the shredded fish business development strategy through a mix marketing approach used a SO (strengthopportunity) strategy, which seeks to maintain product quality, utilize government's cooperation and support, expand the distribution area by opening a distribution network outside the area, leverage the brand's reputation in the market, and create new products.

Furthermore, Rudy and Prasetya (2018) employed a SWOT analysis to define e-government policies in the local governments of Pemerintah Tana Tidung Regency using information technology. Aslan et al. (2012) developed strategies for sustainable development, international trade policy, and the development of the textile industry.

For their part, Kulshrestha and Puri (2017) state that a TOWS matrix can assist in making strategic decisions by maximizing existing strengths and opportunities. The SWOT analysis' usefulness and preference among companies and academics is thus evident, owing to its simplicity when applied to an organization's strategic planning process, in which analyzing and positioning its resources and environments in the four regions (internal and external) is considered to recognize the basic capacities for decision making (Phadermrod et al., 2019). 


\section{METHOD}

This study is qualitative in nature and descriptive in scope. According to Jonker et al. (2011), the core of qualitative research is to identify the characteristics and structure of phenomena and events in their natural context. In qualitative research, authors try to understand a reality specific to an organization and the phenomena that occur from the perspective of all the parties involved. This qualitative study is based on the idea that knowledge about reality can only be obtained through the "eyes of others."

This research used primary data, which was collected through direct interviews with the owner of Recissbar and analyzed by means of a TOWS analysis. Before using the TOWS matrix, the company's internal and external factors were first evaluated. The internal business environment is a specific state that comes from within a company and can be analyzed to show a company's strengths and weaknesses. As noted by David (2005), the internal environment includes management, marketing, finance/accounting, production/operations, research and development, and management information systems.

According to Amirullah (2015), one of the simplest ways to understand and analyze a company's internal environment is through a functional approach. The qualities of a business itself (strengths and weaknesses) can be seen in the various business functions that exist and are carried out within the company, such as marketing, finance, and human resources.

External environmental analysis is defined by David \& David (2016) as a process used by the main strategic planner to evaluate external factors in order to identify opportunities or threats to the company. The TOWS matrix is employed to systematically improve a business strategy by considering the relationship between strengths (strengths), weaknesses (threats), opportunities (opportunities), and threats (threats). The effects of internal and external factors can be replaced in such a matrix. As shown in Table 2, the TOWS matrix can be used to create companies, as well as marketing strategies for businesses.

Table 2. TOWS matrix

Tabla 2. Matriz DOFA

\begin{tabular}{ccc}
\hline IFAS - EFAS & Strength $(\mathrm{S})$ & Weakness $(\mathrm{W})$ \\
\hline Opportunity $(\mathrm{O})$ & SO strategy & WO strategy \\
\cline { 2 - 3 } & $\begin{array}{c}\text { Create a strategy that uses } \\
\text { strengths to take advantage } \\
\text { of opportunities }\end{array}$ & $\begin{array}{c}\text { Create a strategy that minimizes } \\
\text { weaknesses to take advantage of } \\
\text { opportunities }\end{array}$ \\
\cline { 2 - 3 } Threat $(\mathrm{T})$ & $\begin{array}{c}\text { ST strategy } \\
\text { Create a strategy that uses } \\
\text { strengths to overcome } \\
\text { threats }\end{array}$ & $\begin{array}{c}\text { Create a strategy that minimizes } \\
\text { weaknesses to avoid threats }\end{array}$ \\
\hline
\end{tabular}


The data collection process was carried out in two stages. First, the owner of Recissbar was asked to identify the company's strengths, weaknesses, opportunities, and threats. Then, he was asked to assign a score using the following criteria:

- A weight for the External Factor Evaluation (EFE) and Internal Factor Evaluation (IFE) matrices:

- A weight of 0.0 indicates that the factor is not important.

- A weight of 0.05 indicates that the factor is less important.

- A weight of 0.10 indicates that the factor is important.

- A weight of 0.15 indicates that the factor is highly important.

- A rating from 1 to 4 on each factor to indicate that:

- $\quad$ Rating of 1: major weaknesses and threats

- $\quad$ Rating of 2: minor weaknesses and threats

- Rating of 3: minor strengths and opportunities

- Rating of 4: major strengths and opportunities

\section{RESULTS}

\section{Internal Environment}

According to the information provided by the owner of Recissbar, four internal elements were identified: reputation, technology, production capacity, and stretch opportunities.

a. Reputation: Recissbar must identify the resources it owns, which include reputation. It is a brand that offers a distinctive type of snack with a special cheese that makes it taste different from similar foods. Customer relationship: Recissbar has not yet established a customer relationship.

b. Technology: Recissbar produces a type of snack that has been influenced by technological advancements. It does not make the best use of technology, especially when it comes to digital marketing. Recissbar has not yet developed Business-to-Business (B2B) sales. That is, it only relies on sales through hypermarkets and Business-to-Consumer (B2C) online sales.

c. Production capacity: Recissbar can produce items based on market demand. Based on its existing competences, Recissbar can take on stretch opportunities to find new opportunities that can be developed.

d. Stretch opportunities: Recissbar shouldfind new resellers, do promotion on social media, and expand cooperation with mini markets to increase sales. Then, the company will be able to assess the level of risk that will be assumed from the many opportunities (risk attitude). Risk attitude through the TOWS analysis.

The strengths and weaknesses were derived from the elements mentioned above. Such strengths and weaknesses, as well as their corresponding weights, are presented in Table 3. 
Table 3. Internal Factor Analysis Summary (IFAS)

Tabla 3. Resumen del análisis de factores internos

\begin{tabular}{lccc}
\hline \multicolumn{1}{c}{ Internal Strategy Factors } & Weight & Rating & Value \\
\hline Strength (S) & & & \\
\hline Good reputation & 0.15 & 4 & 0.6 \\
\hline Trusted because of the delicious taste & 0.15 & 4 & 0.6 \\
\hline Cheap prices & 0.15 & 3 & 0.45 \\
\hline Several flavors & 0.1 & 3 & 0.3 \\
\hline Subtotal & 0.55 & & 1.95 \\
\hline Weakness (W) & & & \\
\hline Unable to get the product in mini markets & 0.15 & 1 & 0.15 \\
\hline No promotion on social media & 0.1 & 1 & 0.1 \\
\hline Lack of online sales management & 0.1 & 2 & 0.2 \\
\hline Not yet doing B2B online sales & 0.1 & 2 & 0.2 \\
\hline Subtotal & 0.45 & 0.65 \\
\hline Total & 1 & 2.60 \\
\hline Source: Created by the author. & &
\end{tabular}

\section{External Environment}

Three external elements were identified: customers, competitors, and government regulations.

a. Customers: Recissbar should be able to find customers that can influence others, such as celebgrams who can provide product reviews. Recissbar should look for customers who consciously buy and use its products. Recissbar has not been able to find many new customers for its products. Recissbar will lose its customers if the taste of its products changes. The number of loyal customers is increasing.

b. Competitors: Recissbar should know well the condition of its competitors (whether direct or indirect), particularly those who sell similar products, in order to make snacks that are different from those of its competitors both in terms of taste and price. Recissbar should be aware of which of its competitors are aggressively marketing their ideas and products so as to be more aggressive in promoting its products. Recissbar should know its competitors' strengths and weaknesses in order to compete on price and quality. Recissbar should identify unexpected new players who could take over the market. This player could be stronger in dominating the market.

c. Government regulations: The existence of government regulations to issue Halal certificates from MUI has a political and legal impact on Recissbar. Recissbar sells its products through hypermarkets and resellers. The nutritional content and composition of the packaging material should be included in government regulations, namely the Food and Drug Supervisory Agency Regulation No. 30 of 2018, as well as in regulations regarding the existence of a Halal certificate for the food sold. This has had a positive effect on Recissbar's economic conditions. In fact, its products will be increasingly in demand because they are safe for consumption by Muslims.

Table 4 lists the opportunities and threats that were identified from the analysis of the external factors mentioned above. 
Table 4. External Factor Analysis Summary (EFAS)

Tabla 4. Resumen del análisis de factores externos

\begin{tabular}{|c|c|c|c|c|}
\hline & External Strategy Factors & Weight & Rating & Value \\
\hline \multicolumn{5}{|c|}{ Opportunity (O) } \\
\hline & Cooperation with mini markets & 0.15 & 4 & 0.6 \\
\hline & Use of social media for product promotion & 0.15 & 3 & 0.45 \\
\hline sales & Management quality improvement to manage online & 0.1 & 3 & 0.3 \\
\hline & B2B online sales & 0.15 & 3 & 0.45 \\
\hline & Subtotal & 0.55 & & 1.8 \\
\hline \multicolumn{5}{|c|}{ Threat (T) } \\
\hline & More famous competitor brands & 0.1 & 1 & 0.1 \\
\hline & Has not yet mastered the local market & 0.1 & 1 & 0.1 \\
\hline & Fewer consumers & 0.15 & 2 & 0.3 \\
\hline & Easy-to-replicate taste & 0.1 & 2 & 0.2 \\
\hline & Subtotal & 0.45 & & 0.7 \\
\hline & Total & 1 & & 2.5 \\
\hline
\end{tabular}

As observed in Table 4, the Opportunity factor has a total score of 1.8 and the Threat factor has a total score of 0.7. According to Table 3, the Strength factor has a total score of 1.95 and the Weakness factor has a total score of 0.65. Opportunity-Threat $(1.8-0.7=1.1)$ and Strength-Weakness (1.95 $0.65=1.3)$. These results are depicted in the TOWS graph in Figure 1.

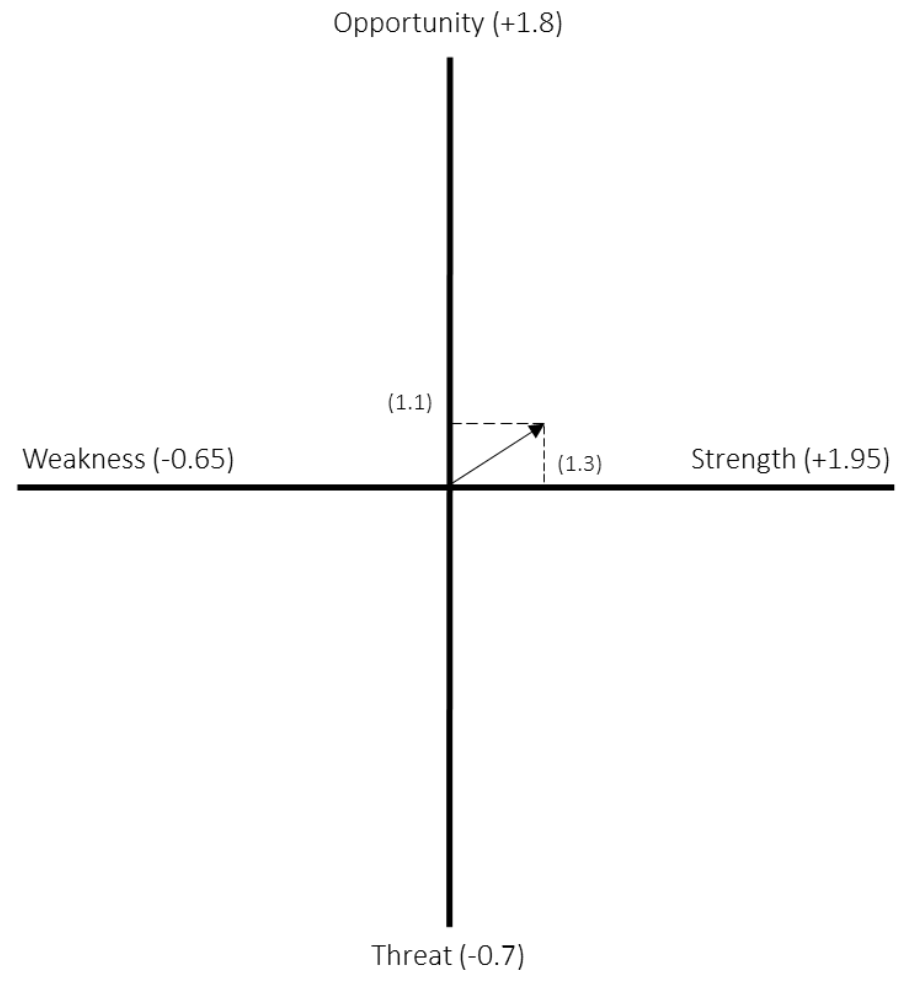

Figure 1. TOWS graph

Figura 1. Gráfico DOFA

Source: Created by the author. 
As evidenced in the TOWS graph, Recissbar is mainly aggressive. In this case, the company is in a favorable condition. By using its current strengths and opportunities, the company can employ an aggressive growth strategy (see Table 5).

Table 5. TOWS matrix

Tabla 5. Matriz DOFA

\begin{tabular}{|c|c|c|}
\hline & Strengths & Weaknesses \\
\hline IFAS & S1: Good reputation & $\begin{array}{l}\text { W1: Unable to get the product } \\
\text { in mini markets }\end{array}$ \\
\hline & S2: Trusted because of the delicious taste & $\begin{array}{l}\text { W2: No promotion on social } \\
\text { media }\end{array}$ \\
\hline & S3: Cheap prices & $\begin{array}{l}\text { W3: Lack of online sales } \\
\text { management }\end{array}$ \\
\hline EFAS & S4: Several flavors & $\begin{array}{c}\text { W4: Not yet doing B2B online } \\
\text { sales }\end{array}$ \\
\hline Opportunities & SO & Wo \\
\hline $\begin{array}{l}\text { O1: Cooperation with mini } \\
\text { markets }\end{array}$ & $\begin{array}{c}\text { Its delicious tastes will open up } \\
\text { opportunities for the company to reach } \\
\text { new target markets. }\end{array}$ & $\begin{array}{c}\text { Improve management quality } \\
\text { to handle online market } \\
\text { demand }\end{array}$ \\
\hline $\begin{array}{l}\text { O2: Use of social media for } \\
\text { product promotion }\end{array}$ & Cooperate with several mini markets & $\begin{array}{c}\text { Promote products on social } \\
\text { media }\end{array}$ \\
\hline $\begin{array}{l}\text { O3: Management quality } \\
\text { improvement to manage } \\
\text { online sales }\end{array}$ & $\begin{array}{l}\text { Promote online sales at several market } \\
\text { places }\end{array}$ & Enhance management quality \\
\hline O4: B2B online sales & $\begin{array}{c}\text { Create new flavors that are different from } \\
\text { those of competitors }\end{array}$ & Do B2B online sales \\
\hline Threats & ST & WT \\
\hline $\begin{array}{l}\text { T1: More famous } \\
\text { competitor brands }\end{array}$ & $\begin{array}{l}\text { Increase cooperation with several mini } \\
\text { markets to dominate the local market }\end{array}$ & $\begin{array}{c}\text { Develop management training } \\
\text { programs to manage online } \\
\text { markets }\end{array}$ \\
\hline $\begin{array}{l}\text { T2: Has not yet mastered } \\
\text { the local market }\end{array}$ & $\begin{array}{c}\text { Increase promotion on social media so } \\
\text { that products are better known }\end{array}$ & Do B2B and B2C online sales \\
\hline T3: Fewer consumers & Create a new product innovation & Do market expansion \\
\hline T4: Easy-to-replicate taste & $\begin{array}{c}\text { Create new flavors that are difficult to } \\
\text { replicate }\end{array}$ & $\begin{array}{l}\text { Create new and different } \\
\text { flavors }\end{array}$ \\
\hline
\end{tabular}

Source: Created by the author.

\section{DISCUSSION}

The following are the various strategies that can be identified from the TOWS matrix presented in Table 5:

1. SO strategies: it's delicious tastes will open up opportunities for the company to reach new target markets, cooperate with several mini markets, promote online sales at several market places, and create new flavors that are different from those of competitors. 
2. WO strategies: improve management quality to handle online market demand, promote products on social media, enhance management quality, and do B2B online sales.

3. ST strategies: increase cooperation with several mini markets to dominate the local market, increase promotion on social media so that products are better known, create a new product innovation, and create new flavors that are difficult to replicate.

4. WT strategies: develop management training programs to manage online markets, do B2B and B2C online sales, do market expansion, and create new and different flavors.

In their study, Taufik and Suprajang (2015) conducted a TOWS analysis using weights for each internal and external factor, whereas this study only identified the company's internal and external factors, developed an EFAS and IFAS matrix, and determined what strategies could be used to overcome existing weaknesses and threats.

Companies can market their products in a variety of ways. An aggressive growth strategy can start by promoting products on social media, cooperating with several mini markets, and doing B2B online sales. The results of this study are in line with those reported by Isra (2017), who recommends an aggressive growth strategy for Indihome internet service marketing. Nevertheless, they are contrary to the findings of Suherman et al. (2019), who recommend the concentric diversification and horizontal diversification strategies.

\section{CONCLUSIONS}

As observed in the EFAS matrix presented here, the total score of the opportunity and threat factors is 2.5 , which suggests that Recissbar responds to existing opportunities by avoiding threats in the same market and has the opportunity to continue to innovate.

According to the IFAS matrix presented here, the total score of the strength and weakness factors is 2.6, which indicates that Recissbar has the strength of having a good reputation and delicious taste.

Based on the TOWS graph, Recissbar couldimplement a growth oriented-strategy, particularly by promoting products on social media, cooperating with several mini markets, and doing B2B online sales.

\section{CONFLICTS OF INTEREST}

The author declares no conflicts of financial, professional, or personal interests that may inappropriately influence the results that were obtained or the interpretations that are proposed here.

\section{REFERENCES}

Abdel-Basset, M., Mohamed, M., Smarandache, F. (2018). An Extension of Neutrosophic AHP-SWOT Analysis for Strategic Planning and Decision-Making. Symmetry, v. 10, n. 4, 116. https://doi.org/10.3390/sym10040116 
Amirullah, S. E. (2015). Pengantar Manajemen. Mitra Wacana Media.

Aslan, I., Çınar, O., Kumpikaite, V. (2012). Creating Strategies From TOWS Matrix For Strategic Sustainable Development of Kipas Group. Journal of Business Economics and Management, v. 13, n. 1, 95-110. https://doi.org/10.3846/16111699.2011.620134

Assauri, S. (2004). Manajemen Produksi dan Operasi edisi revisi. Penerbit FE IU.

Basset, M. A., Mohamed, M., Sangaiah, A. K., Jain, V. (2018). An integrated neutrosophic AHP and SWOT method for strategic planning methodology selection. Benchmarking: An International Journal, v. 25, n. 7, 2546-2564. https://doi.org/10.1108/BIJ-08-2017-0232

Blake, P., Gano-an, J. (2020). Advancing Sustainability Innovation Within The Organizational Learning Sphere. Journal of Business and Finance In Emerging Markets, v. 3, n. 1. 23-32. https://doi.org/10.32770/ibfem.vol323-32

Cacciolatti, L., Lee, S. H. (2016). Revisiting the relationship between marketing capabilities and firm performance: The moderating role of market orientation, marketing strategy and organisational power. Journal of Business Research, v. 69, n. 12, 5597-5610. https://doi.org/10.1016/i.jbusres.2016.03.067

Daft, R. L. (2013). A New Era of Management. Four Salemba.

Daniel, J., Yusuff, R. M., Jassbi, J. (2011). The Best Selection of Strategic Plans in Balanced Scorecard Using Multi-Objective Decision Making Model. African Journal of Business Management, v. 5, ก. 3, 681-686. URL

David, F. R. (2005). Strategic Management: Concepts. Prentice Hall.

David, F., David, F. R. (2016). Strategic Management: A Competitive Advantage Approach, Concepts. (16 th ed.). Pearson-Prentice Hall.

Hautz, J., Seidl, D., Whittington, R. (2017). Open Strategy: Dimensions, Dilemmas, Dynamics. Long Range Planning, v. 50, n. 3, 298-309. https://doi.org/10.1016/j.Irp.2016.12.001

Herdiawan, D., Gunawan, K., Supartono, Ahmadi, Putra, I. N. (2019). Maritime Food Development Strategy as National Economic Pillar using SWOT Analysis Interpretative Structural Modelling (ISM). Journal of Engineering and Applied Sciences, v. 14, n. 20, 7517-7528. https://doi.org/10.36478/ieasci.2019.7517.7528

Jonker, J., Pennink, B. J. W., Wahyuni, S. (2011). Metodologi Penelitian: Panduan untuk Master dan Ph. D. di Bidang Manajemen. Salemba Empat. URL 
Khatimah, H., Mappatoba, M., Abd Rauf, R. (2013). Business Development Strategy Of Shredded Fish Through Approaching Of Mix Marketing On The Industry "Raja Bawang" In Palu City. Agrotekbis, v. 1, n. 5, 464-470. URL

Kulshrestha, S., Puri, P. (2017). Tows Analysis for Strategic Choice of Business Opportunity and Sustainable Growth of Small Businesses. Pacific Business Review International, v. 10, n. 5, 144152. $\underline{U R L}$

Longhurst, G. J., Stone, D. M., Dulohery, K., Scully, D., Campbell, T., Smith, C. F. (2020). Strength, Weakness, Opportunity, Threat (SWOT) Analysis of the Adaptations to Anatomical Education in the United Kingdom and Republic of Ireland in Response to the Covid-19 Pandemic. Anatomical Sciences Education, v. 13, n. 3, 301-311. https://doi.org/10.1002/ase.1967

Isra, M. (2017). Alisis strategi pemasaran produk indihome dengan menggunakan qspm pada pt. Telkom witel makassar. [Thesis, Master Program Management, Hasanuddin University]. URL

Madurai Elavarasan, R., Afridhis, S., Vijayaraghavan, R. R., Subramaniam, U., Nurunnabi, M. (2020). SWOT analysis: A framework for comprehensive evaluation of drivers and barriers for renewable energy development in significant countries. Energy Reports, v. 6, 1838-1864. https://doi.org/10.1016/j.egyr.2020.07.007

Oliver, J. J., Parrett, E. (2018). Managing future uncertainty: Reevaluating the role of scenario planning. Business Horizons, v. 61, n. 2, 339-352. https://doi.org/10.1016/j.bushor.2017.11.013

Pearce, J. A., Robinson, R. B. (2013). Strategic Management: Formulation, Implementation, And Control. (9 ed.). Salemba Empat.

Phadermrod, B., Crowder, R. M., Wills, G. B. (2019). Importance-Performance Analysis based SWOT analysis. International Journal of Information Management, v. 44, 194-203. https://doi.org/10.1016/J.IJINFOMGT.2016.03.009

Punt, A. E. (2017). Strategic management decision-making in a complex world: Quantifying, understanding, and using trade-offs. ICES Journal of Marine Science, v. 74, n. 2, 499-510. https://doi.org/10.1093/icesjms/fsv193

Rangkuti, F. (2015). Analisis SWOT Teknik Analisis Membedah Kasus Bisnis. Gramedia Pustaka Utama.

van Rijmenam, M., Erekhinskaya, T., Schweitzer, J., Williams, M. A. (2019). Avoid being the Turkey: how big data analytics changes the game of strategy in times of ambiguity and uncertainty. Long Range Planning, v. 52, n. 5, 101841.

https://doi.org/10.1016/i.Irp.2018.05.007

Rudy, R., Prasetia, A. M. (2018). Swot Analysis and Tows Matrix E-Government on Tana Tidung City of Kalimantan Utara. Elinvo Electronics, Informatics, and Vocational Education, v. 3, n. 1, 46-51. https://doi.org/10.21831/elinvo.v3i1.19518 
Shpak, N., Naychuk-Khrushch, M., Kohut, U., Honchar, M., Sroka, W. (2020). The Usage of Modern Instruments of Business Planning Administration for Small Enterprises: A Case Study Analysis. Central European Business Review, v. 9, n. 1, 20-42. https://doi.org/10.18267/j.cebr.227

Shujahat, M., Hussain, S., Javed, S., Malik, M. I., Thurasamy, R., Ali, J. (2017). Strategic management model with lens of knowledge management and competitive intelligence: A review approach. VINE Journal of Information and Knowledge Management Systems, v. 47, n. 1, 55-93. https://doi.org/10.1108/VJIKMS-06-2016-0035

Suherman, A. T., Praptono, B., Tripiawan, W. (2019). Analisis strategi pemasaran dengan pendekatan TOWS. e-Proceeding of Engineering, v. 6, n. 2, 6170. URL

Taghavifard, M. T., Mahdiraji, H. A., Alibakhshi, A. M., Zavadskas, E. K., Bausys, R. (2018). An Extension of Fuzzy SWOT Analysis: An Application to Information Technology. Information, v. 9, n. 3, 46. https://doi.org/10.3390/info9030046

Taufik, M. I., Suprajang, S. E. (2015). Analysis threats, opportunity, weakness, strengths (tows) Sebagai Landasan Dalam Menentukan Strategi Pemasaran pada PR. Semanggimas Agung Boyolangu Kabupaten Tulungagung. Riset Mahasiswa Ekonomi (RITMIK), v. 2, n. 2, 147-168. URL

Teece, D. J. (2019). A capability theory of the firm: an economics and (Strategic) management perspective. New Zealand Economic Papers, v. 53, n. 1, 1-43. https://doi.org/10.1080/00779954.2017.1371208

Vargas-Hernández, J. G., Calderón Campos, P., Palomares Salceda, F., Almanza Jiménez, R. (2017). New perspective in the design of quality management systems. Independent Journal of Management \& Production, v. 8, n. 3, 1059-1072. https://doi.org/10.14807/ijmp.v8i3.620

Wang, J., Wang, Z. (2020). Strengths, Weaknesses, Opportunities and Threats (SWOT) Analysis of China's Prevention and Control Strategy for the COVID-19 Epidemic. International Journal of Environmental Research and Public Health, v. 17, n. 7, 2235. https://doi.org/10.3390/ijerph17072235

Wildan Putera, D. A. (2016), Analisis SWOT Layanan Indihome PT. Telekomunikasi Indonesia [Magister Thesis, Mercu Buana University]. URL

Zakeri, S., Yang, Y., Hashemi, M. (2019). Grey strategies interaction model. Journal of Strategy and Management, v. 12, n. 1, 30-60. https://doi.org/10.1108/JSMA-06-2018-0055 